\title{
MODERN DESIGNS: HISTORY AND MEMORY IN LE CORBUSIER'S CHANDIGARH
}

\author{
Nabaparna GHOSH \\ University of Virginia, Charlottesville, United States of America \\ E-mail: nabaparna@gmail.com
}

Received 14 November 2015; accepted 09 May 2016

\begin{abstract}
Located at the foothills of the Sivalik Mountains, Chandigarh was the dream city of independent India's first Prime Minister Jawaharlal Nehru. In 1952, Nehru commissioned the Swiss-French architect Le Corbusier to design Chandigarh. Scholars often locate in Corbusier's plans an urban modernity that required a break with the past. Moving away from such scholarship, this article will argue that Chandigarh marked a climactic moment in Le Corbusier's career when he tried to weave together modern architecture with tradition, and through it, human beings with nature. A careful study of the cosmic iconography of Chandigarh clearly reveals that nature for Le Corbusier was more than a vast expanse of greenery: it was organized in symbolic ways, as a cosmic form emblematic of Hindu mythologies. I will argue that in addition to local conditions - economic and cultural - that impacted the actual execution of Le Corbusier's plans, cosmic iconography shaped a modernism profoundly reliant on Hindu traditions. This iconography also inspired a new generation of Indian architects like Balkrishna Vithaldas Doshi (1927 - present). Doshi played a key role in authoring the postcolonial architectural discourse in India. Following Le Corbusier, he advocated an architectural modernism anchored in sacred Hindu traditions.
\end{abstract}

Keywords: Le Corbusier, Chandigarh, B.V. Doshi, capitol, postcolonial architecture, open hand.

In August 1947, India achieved independence from nearly two hundred years of British colonial rule. This freedom, however, came at a cost. On the eve of independence, the country was partitioned into the postcolonial nation-states of Pakistan and India. Divided on the grounds of religion, partition required the Muslims of India to move to Pakistan. In a similar way, Hindus and Sikhs living in the region that now became Pakistan were forced to move to India. The movement of people across the border resulted in chaos. With houses uprooted, families separated, millions of men, women, and children suffered terrible fates. To this end, the partition remains one of the most disastrous events in the history of South Asia.

Partition divided Punjab, a state in northern India. The ancient city of Lahore that used to be the capital of Punjab passed on to Pakistan. That part of Punjab that now remained in India required a new administrative capital. The cities of Simla and Jullundur served as capitals for a short time. Standing at the heart of the Himalayas, Simla was difficult to administer; Jullundar, on the other hand, was weak from a defense point of view. To make matters worse, these cities, already heavily populated, were ill equipped to house the large numbers of men and women who had moved from West Punjab (Randhawa 1968). A new capital of Punjab that could govern the state in effective ways, and also house the influx of people, was now necessary.

The initial impetus to build a new capital came from Prime Minister Jawaharlal Nehru. As the first Prime Minister of independent India, Nehru's ideas of modernity were anchored in scientific and industrial growth. Departing from Gandhian visions of the village as the heart of India, Nehru wanted to promote cities and industries to eliminate poverty. As the leader of independent India, he envisioned cities as symbols of the country's progress. He therefore called for building "a new administrative city [for Punjab] unfettered by the tradition of the past... an expression of the nation's faith in the future." (Nehru 1954). This declaration led to the planning of Chandigarh, a city that became the capital of Punjab and embodied Nehru's faith in science and industry. 
Given the tumultuous history of partition, Nehru's call to reject tradition and build the capital of Punjab in new ways is understandable. He recruited architects from abroad to minimize the impact of Indian tradition on the new city. It was the Swiss-French architect, Le Corbusier who planned Chandigarh. Known for his minimalist styles and straight-line designs, Le Corbusier planned the city according to the function of its spaces. This was a practice new to the Indians. The business district formed the nucleus of the city, while the residential districts were located away. Glass and steel skyscrapers represented a new spatial order that enforced total state control (Kalia 1999). These modern plans, however, were far from modern: the planning of Chandigarh lacked proper surveys, analytical, economic, and social data (Evenson 1969). Instead, different notions of the modern emerged as part of the planning process, blurring the lines between the East and the West (Prakash 2002).

Although scholars are unanimous that the modern spaces of Chandigarh marked a break with the past, cosmic symbols etched on the buildings recount a different story. Often overlooked, these symbols and images had mythic contents drawn from the Hindu scriptures. Balkrishna Vithaldas Doshi (1927 present), an architect, who worked with Le Corbusier in Paris and later supervised the plan of Chandigarh, first analyzed this iconography at length. According to him, in planning Chandigarh, Le Corbusier preserved Indian tradition by invoking the concept of the sacred in Hindu religion. What Doshi does not acknowledge, however, is that Le Corbusier's understanding of Indian tradition was only partial. Given the diverse population of India, Hindu religion clearly does not represent all Indian traditions. Yet, the importance of Hindu influences in Le Corbusier's plans cannot be ignored. It marked a culmination of his efforts to integrate architecture with the landscape, and through it, fuse the universal with the particular. In Europe, he had already carried out small experiments to bring together the built and natural worlds. The plan of Marsielle Unite d'habitation is an example. The cosmic iconography of Chandigarh, which remains largely ignored in history, marked the pinnacle of such efforts.

\section{Planning Chandigarh, modern designs}

According to Nehru, the city was a pedagogic tool to educate citizens in the etiquettes of modernity. $\mathrm{He}$ explained that Chandigarh, besides working as the "soothing balm on the wounded spirit of Punjab" (Nehru 1954), could drive India towards a democratic and secular future. Going beyond the Gandhian philosophy that the village symbolized India, he encouraged the growth of modern, scientific cities as engines of modernity. In a speech delivered at the inauguration of the Punjab High Court in Chandigarh, Nehru argued that it would have been "a great mistake and foolishness" if the people of Chandigarh placed an old city as their capital, as it would lead to a "mentally stagnant and backward" Punjab. He went on to say that he had welcomed the great experiment of Chandigarh, because

It hits you on the head and makes you think... You may squirm at the impact but it has made you think and imbibe new ideas... not being tied down to what has been done by our forefathers, but thinking in new terms (Nehru 1954)

Rejecting the influences of the past, Nehru leaned on European rationalism and industrial modernity to envision India's future. A modern city - an emblem of industrial progress - was at the heart of his plans. To free the city from tradition he recruited an American Firm, M/s. Mayer, Whittlessay and Glass to plan Chandigarh in 1950. The American architect and planner, Albert Mayer, led the firm and recommended a city with a curvilinear plan with roads north-south or east-west, and a main business center on the top of the town below the hills (Randhawa 1968). Matthew Nowicki, a Polish architect assisted Mayer. Unfortunately, Nowicki died in an air crash in Egypt. Following this, Mayer did not want to complete the remaining work. He requested the Indian government to find a new city planner.

Consequently, P. N. Thapar, chief administrator of the Chandigarh Project, and P. L. Verma, his assistant, visited Europe to find a new city planner. In November 1950, they met Le Corbusier in his office in Paris and requested him to name two architects who they could appoint to plan the new capital (Randhawa 1968). After a month, they returned to Paris to request Le Corbusier to accept the post of "Government Architectural Adviser" and take up the work of planning Chandigarh. By this time, they had already visited London and appointed architects Maxwell Fry and his wife Jane Drew for the project. Le Corbusier accepted the offer and asked them to also appoint his cousin, Pierre Jeanneret, with whom he had worked for quite some time.

In February 1951, Le Corbusier visited India and surveyed the site. Inspecting the land, he produced a master plan on the spot. This master plan was "futurist, a poem, a hymn to technology to speed and movement to a man world of vast dimensions" (Randhawa 1968). The plan resounded Nehru's promise, 
We are trying not so much to express ourselves or obtruse ourselves but to develop the city as modern self-confident Indians would if there were such a group (Nehru 1954).

In 1959, in an edict for the city Le Corbusier clearly laid out his goals in planning Chandigarh. The edict declared that the planners would behave like "guardians and prevent the whims of individuals" (The Establishment Statute of the Land 1959). Space would be allotted according to the basic function of each part of the city. According to this plan, the new city would have clearly defined business and residential sectors. Similar to Mayer, Le Corbusier imagined the nucleus of the new city comprised of civic and commercial buildings - the Capitol - built around a chowk or piazza. He planned the Capitol at the top of the town to take advantage of the presence of the mountains, the hills and agricultural life - villages, sugar cane, wheat fields, colza fields, cows, oxen and bulls. He argued that the agrarian life touching the Capitol, separated by one single pit of four meters, connected the modern times to the "bucolic symphony" (Le Corbusier 1961).

Outside the Capitol, the rest of the city had "sectors" and space left open for parks and monuments. The sectors, residential parts of the city, were containers of family life. Le Corbusier planned these to restrict the inroads of automobiles. Usually in Indian cities, houses abutted on the streets and the separation between residential spaces, office districts, and streets were not well defined. In Le Corbusier's plans, streets covering the area of the sectors formed a mesh, restricting the movement of all automobiles and eliminating danger for the pedestrians. As he pointed out, this sector grew from an ancestral and valid geometry established in the past on the stride of a man, an ox or a horse, but henceforth adapted to match mechanical speeds.

To allow the city to grow without the touch of tradition, the edict of Chandigarh further mandated that streets and parks should not have personal statues. Instead, the city was supposed to be the "breather of a new sublimated spirit of art" (The Establishment Statute of the Land 1959). With the new plan, Le Corbusier claimed to have resolved the dilemma that was holding back India's growth as a modern country. As he pointed out, India had an ancient peasant culture. Hindu temples carved in stone and Muslim temples in red stone represented the geometric architectural beauty of that culture. These, however, were not forms fit for modern civilization (Joshi 1999). His goal was to modernize Indian architecture, while keeping the agrarian forms intact (Le Corbusier 1995).
Although Le Corbusier planned for a modern city, untarnished by tradition, his plans underwent significant changes when implemented. While building Chandigarh, the planners themselves did not always follow the rules of the edict. For instance, Pierre Jeanneret designed the Gandhi Smarak Bhawan to keep alive the memories of Gandhi and the history of India's fight for independence (Fig. 1). The Bhawan, a three-winged structure stood amidst a pool of water; its pointed forms symbolized Gandhian thoughts, and the angled structures suggested the sharp edge of truth. The rounded forms, on the other hand, indicated harmony (Pandit 1969).

In addition, the requirements of men and women who worked and lived in Chandigarh altered the use of space. They disagreed with several aspects of Le Corbusier's plans. For example, one of the earliest buildings that Le Corbusier designed was a massive, sculptural High Court that won praise from architects and critics. But the High Court judges, men who used it the most, dissented. They openly rejected Le Corbusier's decree that vehicular traffic had to approach the building from a sunken drive. Instead, they drove along the paths that the architects had laid out for the pedestrians, and parked their cars under the great arches that reached the building's parasol roof. Le Corbusier indignantly photographed the grease spots left by the cars beneath the splendid arches, and snapped: "What sort of judges are these who do not obey the traffic laws?" (The Sikh Times 1959).

Five of the eight judges who worked at the court decided that they did not like the abstract cubist tapestries Le Corbusier designed for the courtrooms. When they hauled these down, he remarked that "they should confine themselves to being judges of law", and "not set themselves up as judges of art" (The Sikh Times 1959).

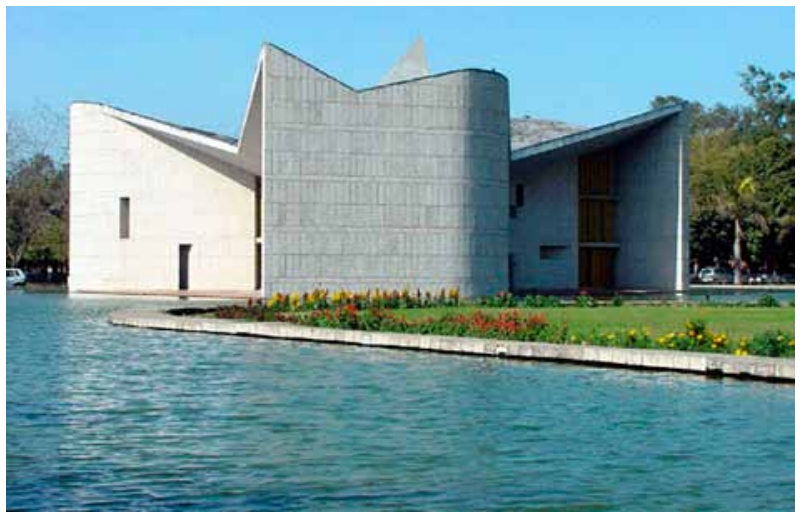

Fig. 1. Gandhi Smarak Bhawan (Gandhi Bhawan 2015) 
Groups of peasants also disagreed with Le Corbusier's plan. A common practice among them was to keep buffaloes near their houses. Le Corbusier's sectors did not leave enough space for such practices. This led to a general feeling of animosity among the peasants and other residents of Chandigarh. Their anger reached its climax when they called for postponing the building of the legislative assembly. A public-opinion poll published by Punjab's leading English-language newspaper, the Tribune, called for postponing the legislative building as a measure of economy. When this happened, an angry Le Corbusier retorted: "What do grocers and peasants know of the work I am doing" (The Sikh Times 1959).

Furthermore, the residents of Chandigarh argued that the plan of the city, built from the periphery inward, reinforced caste hierarchies. They complained that the town plan facilitated a built-in caste system, with groups divided by blocks and identified by the color of their water cisterns. Le Corbusier, at the center of controversy, disliked the furor, but clearly was not surprised by it. "I am like a lightning conductor," he declared. "I attract storms." (Lightning at Chandigarh 1959).

Meanwhile, Maxwell Fry and Jane Drew reached India. They found that the place was not a desert as they had imagined. Instead, they described the city of Ambala in Punjab with its cantonment bungalow as "Kiplingesque": a village with mud huts was a thing of timeless beauty. They were excited by the harmony that shaped this diverse country:

The track by the pond, water buffaloes submerged to their noses, the arching Peepul tree with its gnarled roots, women at the well, temple bells, woodsmoke, tiny courtyards where beyond, in deepening shade, the small complications of domesticity are received into white structural form (Drew 1961).

Fry described the remnants of Mughal architecture and traditional villages in India as inspiring. But he approached the plan of Chandigarh with professional and modernist self- confidence. He wrote that "an approach to architecture that is common to all countries" had finally seen the light of the day (Joshi 1999). This approach prioritized functional analysis over the act of creation, producing a style that could be applied to all architectural problems. Informed by this approach, he looked at Mughal architecture and traditional village building, but decided to treat the hot season as dominant. He concluded that protection from the sun and from the dust-laden winds of the hot season was the architectural imperative, the rest secondary.
In a similar way, for better accommodation, Pierre Jeanneret, ascertained the intricacies of Hindu religious observance in the domestic routine. He emphasized the separation of sexes, castes, occupation, customs of sleeping and relaxation brought about by the climate, the need for sleeping on the roof or in the garden, and why there must be a barsati (rooftop room) in Indian houses. After describing the difficulty of pinning down the architectural requirement of the changing lifestyle in India, he also called for changes in architectural styles. He wrote a brief newspaper article with a plea to the inhabitants to allow the architects to bring this change, "to put a little confidence in the designers who are specialists..." (Joshi 1999).

Fry and Drew also took under consideration the income of the city dwellers in tailoring their plans. Drew planned Sector 22 that housed the poorer groups of city dwellers, the peons and the sweepers, who did not have motorcars. Here terrace housing shaped a total street and community design in a way impossible in the detached housing of the rich. The street and the square formed a whole, varying somewhat, and depending on whether the housing faced south, north, east or west. The streets were kept narrow with shade trees planted on one side.

The cheapest houses in Chandigarh were the houses of the sweepers, provided with minimum housing accommodation. This meant two rooms, a verandah kitchen, courtyard and water borne sanitation and washing facilities. The compound usually had walls for security, and sleeping in the compound was possible in hot weather. As Drew explained, originally built to a plan which strictly followed the established custom and taboos, these houses later took on a modern form which had less passage way, where sweepers would cross the living room, and where balconies had no purdah or covers (Drew 1959).

While making modifications in the existing plans, Drew encouraged Le Corbusier to set up certain signs and architecture-bearing-symbols between the edifices of the Capitol. By that time, Le Corbusier had already experimented with architecture bearing symbols in Europe. By the 1930s, his interest in symbolic architecture that tried to fuse the built and natural worlds had become clear (Menin, Samuel 2002). He had invented symbols to revive a spiritual environment where human beings could live with nature. For example, between 1940 and 1952, he designed the famous Marsielle Unité d'habitation. As Vincent Scully has pointed out, the Marseilles roof transported human beings back to the time of the Mediterranean religion and myth (Scully 1991). With walls surrounding the 
roof, one could not see the city anymore; left with a view of the sky and the hills, the roof marked a symbolic union of humans and nature. In a similar way, he had built the cabanon, a log cabin with a small studio ten feet away. He used the modular dimension, a mathematical dimension of the cosmos, to order space within the cabanon (Menin, Samuel 2002).

When Drew suggested that Le Corbusier set up architecture bearing symbols, he saw this as an opportunity to continue his experiments on architecture and landscape. The symbols on the monuments he designed in the Capitol complex displayed the essential unity of humans, nature, and the cosmos. These structures spatially and symbolically represented the primal bond that existed between humans and the natural world. Hindu motifs etched on the buildings depicted the sun, trees, animals, and rivers as the source of life and vitality on earth. In such portrayals, the motifs emphasized the basic harmony and interdependence of nature and humans.

Often overlooked, the cosmic iconography of Chandigarh marked an important phase in Le Corbusier's career: it formalized the shift from a technological to a more natural phase. At the heart of this shift was a new way of viewing space. Modern aviation deeply influenced this view (Constant 1991). Riding in an airplane, Le Corbusier could now leave the ground and observe the world from above. This bird's eye view helped him to see the world from a distance, almost through the eyes of a spirit. The actual physical experience of leaving the ground and viewing the world from space reinforced cosmic references in his work.

Most monuments in the Capitol Complex, for instance, celebrate the mystic power of the sun. Situated at the center of the universe, the sun holds together the cosmos; its energy fuels the symbiotic relation between man and nature making life possible on earth. Offering tribute to the sun, the monuments highlight this symbiosis. The 24 Solar Hours monument, for example, stands on an inclined face of a hill tracing the path of the sun between the two solstices. Standing near it, is the Tower of Shadows, another monument built along the path of the sun. Le Corbusier described it as "a very open hall, very high and shadowy, ideal for meditation" (Le Corbusier 1952: 17). He went on to add that the sun can be controlled at all four cardinal points of an edifice and even manipulated in a hot country to reduce temperatures. These monuments draw attention to the centripetal forces of the sun, the source of all energy on earth. At the same time, standing at the center of the universe, the sun governs all. The monuments emphasize this, pointing to the ruling men's ability to govern all.

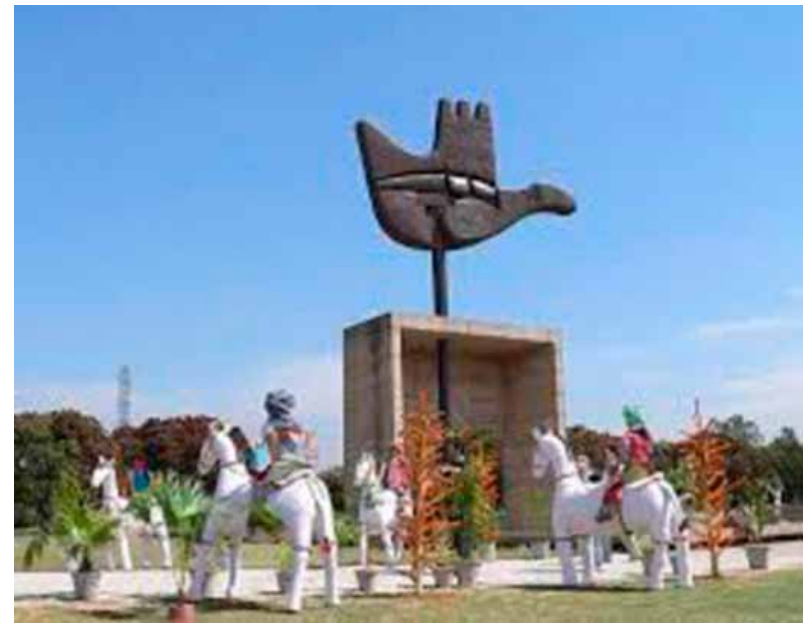

Fig. 2. The Open Hand monument at Chandigarh (The Open Hand Monument 2015)

Chandigarh also gave form to the theory of the modulor that Le Corbusier formulated during the World War II. The modulor was a new scale of measurement based on human height, with hands raised. Le Corbusier pointed out that the Renaissance had not followed the postulate, which in the modulor placed man at the center of the drama; its solar plexus being the key to the three measures which expressed the occupation of space by its members. Earlier, he had successfully used the modulor in building the Marsielle Unité d'habitation. With Chandigarh, he had now used modulor to plan an entire city. In the anthropomorphic city of Chandigarh, the public and administrative buildings were at the head, while all other buildings were in the bowels of the city.

From 1952, the famous Open Hand occupied the plan of the Capitol. Located near amango grove and shining against the hills the monument looked like giant bird (Fig. 2). According to Le Corbusier, the structure embodied the philosophy of life. He compared the Open Hand to a tree with branches sprouting every year (Le Corbusier 1961). To this end, the Open Hand was his gift to mankind. It stood as a symbol of resilience and survival in the face of adversity. Rising against the Himalayas, the Open Hand rotated with the flow of the wind. As Le Corbusier explained, these were not aimless rotations (Le Corbusier 1995). Instead, the movements symbolized the changes in life, the everyday struggles, the fight to earn the daily bread, the ultimate triumph of mankind, and the possibility of filling empty hands with rewards. He writes:

[The Open Hand] Open to receive and open to give; which is the ineluctable destiny of the mechanical civilization which today is making use of its machines in a dangerous way, forges that its open hand 
shall be filled with consumer goods

(Le Corbusier 1961)

Powered by the wind, the Open Hand symbolized how human beings in their daily struggles could meaningfully draw on the resources of nature. This required harmony between humans and nature. Indeed, the Open Hand signified harmony: the harmonization of the second Mechanical Era, turning the page on the first era of a hundred years, which had just upset the world and provoked actual disorder.

The significance of Le Corbusier's cosmic iconography, however, was not confined to the spaces of Chandigarh. It inspired a new generation of Indian architects who in their work wanted to strike a balance between modernity and tradition. Leading this group was the architect Balkrishna V. Doshi. Synthesizing modern architecture with vernacular traditions, he made significant contributions to the postcolonial architectural discourse in India. His goal was to employ space in building a new national identity that valued both modern and traditional ways of life. In his 1986 interview with Carmen Kagal, he famously proclaimed that Le Corbusier's ideas influenced all his work (Doshi 1986). In particular, he had drawn upon the cosmic iconography of Chandigarh to craft a new national identity. In the symbols grafted on the concrete buildings he saw a peaceful union of industrial modernity with sacred Hindu traditions. He explained that this harmony was very important in postcolonial India. Architectural patterns that portrayed this unity could help Indians preserve their traditions in an unpredictable modern world. To this end, several of his buildings, including his own studio, fused modern styles with sacred Hindu traditions.

\section{Memory and history in Chandigarh}

Balkrishna V. Doshi is a famous architect, educator, and a pioneer of postcolonial architecture in India. Born in 1927 in Poona (Pune), a city near Bombay (Mumbai), he later joined the J. J. School of Art in Bombay. Unfortunately, his education at the J. J. School left him deeply unsatisfied and he quit to pursue a degree in London. It was at this time, in London, that he met Le Corbusier. Impressed by Le Corbusier's ideas, he moved to Paris to work with him. In 1955, when Doshi finally returned to India he brought with him the influences of Le Corbusier. These were the years immediately after independence. India was trying to move away from its colonial past, and define a new national identity. Doshi partook in these efforts, producing a modern national identity through art and architecture.
In 1986, Doshi in an interview with Carmen Kagal described his experiences of working with Le Corbusier. In this interview, he pointed out that in India Le Corbusier had made a "pact with nature" (Doshi 1986: 5). This pact was an outcome of Le Corbusier's interactions with a certain kind of nature that he had not seen before; he saw the burning sun, the scorched fields, the furious monsoons, and felt the allure of tropical nights for the first time in Chandigarh. At the same time, the endless ranges of the Himalayas fascinated him. The first thing that he did in Chandigarh was to sketch the Himalayas. The barren land, the mango trees, and the bull with the horns grazing the grounds were all new to him. The blue sky full of birds enthralled him. It made him sense the need for air circulation and its connectedness to the open sky. It was at this time that he made a pact with nature and decided to offer the city he was designing to the Himalayas, and the untamed nature.

In the many conversations that Le Corbusier had with Doshi, he mentioned the silhouettes of domes that represented the sky and the kund (pond) that represented water bodies; on starry nights, he would talk about the moon, the stars, and the cosmic forces. He looked at the skyline of Indian temples, arches and domes, all of which eventually informed his designs. His interest in using symbols was to express the essence of what the Indians believed was true (Doshi 1990). He had written several letters to Nehru trying to understand the traditional concepts of Indian architecture and planning. In these letters he requested Nehru to suggest symbols fit for the Capitol complex. After consulting scholars, Nehru wrote back saying that he was not an expert and that Le Corbusier derive his own symbols.

Doshi writes that miniature painting that flourished under the Mughals deeply inspired Le Corbusier. He spent a lot of time looking at Indian miniatures and specially admired devotional paintings. One painting that showed Krishna and Radha dancing caught Le Corbusier's attention. He observed that in the painting, "front and back are both shown, how you can twist the plane to get a complete image". At that time, the problem that was intriguing him was how to get another dimension within the same plane. The painting resolved his dilemma; he made the formwork go against the nature of the concrete, that is, he placed shuttering planks diagonally on the normally vertical formwork so that the shadows were cast diagonal while the basic level remained horizontal. This was done with the idea that the plane must get another dimension through shadow (Doshi 1986)

Doshi states yet another way in which miniature paintings inspired Le Corbusier. The paintings allowed 
for exceptions: in these paintings suddenly something went out of the frame; out of all the figures painted, one turned its head. For him, exceptions were important to prove the rule. This came out of the realization that rigid structures were not the answer if structures were to survive (Doshi 1986). Another painting that inspired Le Corbusier was that of a woman, belonging to the poorer classes, who sat full of grace and dignity with a child on her lap. Behind her was a vast open space. Examining the painting, Le Corbusier mentioned that in spite of the frugal living conditions, the grace and dignity of the woman could be clearly seen. Modern Indian cities, he argued, must provide for such dignity and respectable lifestyles.

In another article, titled "Le Corbusier: A Personal Reading," Doshi writes that inspired by the Mughal paintings, Le Corbusier traveled to Delhi to learn from the Mughal architecture at the Diwan I Khas of the Red Fort. As Doshi explains, the use of temporary devices, such as cloth swings in classical architecture to create a shade from the hot Indian sun charmed him. He discovered the forms of Indian shadows, silhouettes, trees, ghats (embankments) and water bodies. Based on these, he interpreted the spiritual versus material, and the temporary versus the eternal, manifest in the Indian ways of life. With these impressions, he talked about giving an expression to these relationships, and their eternal harmony through a language appropriate for the time.

Doshi goes on to explain how an eye for the past informed Le Corbusier's designs in Chandigarh. For instance, even though Le Corbusier had been drawing trees for a long time, he used it in his plans because he had learnt that Indians considered the tree as sacred. Sarnath sculptures talk of "tree of life" because it bears fruit, provides wood to make shade and sculptures, and in the end wood for fire to sustain life. Giving everything, trees also stay perfectly balanced, adapting to the seasons and when full grown, replicating and producing a regenerative cycle. In a similar way, Doshi points out several drawings of bulls on the concrete walls of the Assembly and the Secretariat. He argues that the Brahman bull from Mohenjodaro fascinated Le Corbusier, as it was Lord Shiva's vehicle (Doshi 2009).

Doshi also points out other animals, the serpent and the tortoise, considered sacred in Hindu religion that found their way to Le Corbusier's designs. Placed at the entrance of Shiva temples, the tortoise had sacred meanings in India. It was a symbol of controlling one's senses, conveying that in order to discover oneself, one must search within. The serpent too is a symbol of Kundalini: the spiritual potential in every human being that lies at the base of the spine, coiled like a snake (Doshi 2009). Once awakened through yoga and meditation, it rises, producing spiritual knowledge and mystical powers. It also represents the casting off one's skin to revitalize oneself. Doshi observed the presence of these animals in many paintings in the buildings that Le Corbusier designed.

In a similar way, human body parts are also considered sacred in Hindu religion. The feet, for example, are described as holy and drawn outside temples to depict Lord Vishnu's footprints. This, in turn, indicates the Lord's presence inside the temple. Newly married couples also imprint their footprints as a ritual when they visit their neighbors' houses. They leave impressions of their hands on walls to convey the prosperity that they bring along with them. Doshi described that Le Corbusier used these symbols, along with a plethora of other symbols of gods, goddesses, monkeys and elephants in the Hindu cosmic order to easily communicate with the common Indian people (Doshi 2009). In addition, he employed the images of sunrise and sunset, and the solar cycle for 365 days that urged the viewers to remember the rhythmic order of everyday life in Hindu religion.

Regarding the Open Hand, Doshi offers new insight. According to him, Le Corbusier believed that hands were God's unique gift; the hands, a flexible tool, were like machines performing the action of giving and taking. Doshi explained that Le Corbusier used to say that neither traditions nor rules were permanent. People make rules, and with skill, experience and dexterity of the hand, tradition can be rewritten. That was why he built the Open Hand: to rewrite tradition.

Le Corbusier's philosophy informed the works of Doshi. In 1956, Doshi started his own architectural firm under the name Vastu Shilpa [environmental arts]. He later expanded it as the Vastu Shilpa Foundation for Environmental Design. The word vastu refers to a Hindu science of architecture that existed in ancient India. Occasionally, it included Buddhist architectural practices. As a scientific system, vastu had its own patterns, measurements, and geometry. Originating in ancient India, its principles reinforced the primal bonds between human beings and nature. Naming his firm after vastu, Doshi built on Le Corbusier's legacy of combining architecture with landscape, and through it, humans with nature/ tradition. Vastu Shilpa Foundation [VSF] explained architecture as a filter to connect the traditional with modern practices. The goal of the foundation was to invent architectural tools to interlace traditional with modern structures.

As the firm explained, the environment had changed dramatically over the years, but mankind had 
not. VSF tried to capture this timelessness of human existence. As the firm's website describes, VSF strove to revive "timeless qualities of human nature could provide a thread of continuity and familiarity amongst different cultures and different moments in history." Based on this idea, VSF tried to preserve the traditional principles of architecture - mythical sense, symbolism, and timelessness - in modern buildings. Doshi pointed out that these principles could shape modern buildings that had strong ties with nature and the country's past. These buildings then played a key role in his efforts to craft a new national identity through architecture.

Additionally, Doshi invented the Vastu-Mandala (environment-astrology), a scale to determine a proper orientation of buildings that could place them closer to nature. Along with colonnades, skylights and porticos, Vastu Mandala ensured the adequate flow of sunlight and maintained proper ventilation. Drawing on an ancient Hindu science it also promised to keep out the evil, and circulate positive energy.

A classic example of Doshi's work is the Hussain Doshi Gufa, an underground art gallery in Ahmedabad (Fig. 3). Upholding the newly formulated principles of Vastu Shilpa, it is rich in symbolism. The mosaic tiles of its roof resemble that of the Jain temples, and a mosaic snake placed in-between is drawn from Hindu mythology. Buddhist caves of Ajanta and Ellora inspired Doshi to design the interior with circles and ellipses. A cave like structure, the Gufa is oriented in a specific way to draw in maximum sunlight. Similarly, Doshi's own studio, the Sangath, was closely integrated with nature. Surrounding it was vegetation left to grow in the wilderness. A central open courtyard, massive skylights through which sunlight poured in, and trees and greenery surrounding buildings characterized most of Doshi's independent work, which grew in the shadow of Corbusier's ideas of uniting man with nature.

Doshi, like Le Corbusier, explained Hindu religious practices as the cultural tradition of India. Describing the various influences in his work, he had once re-

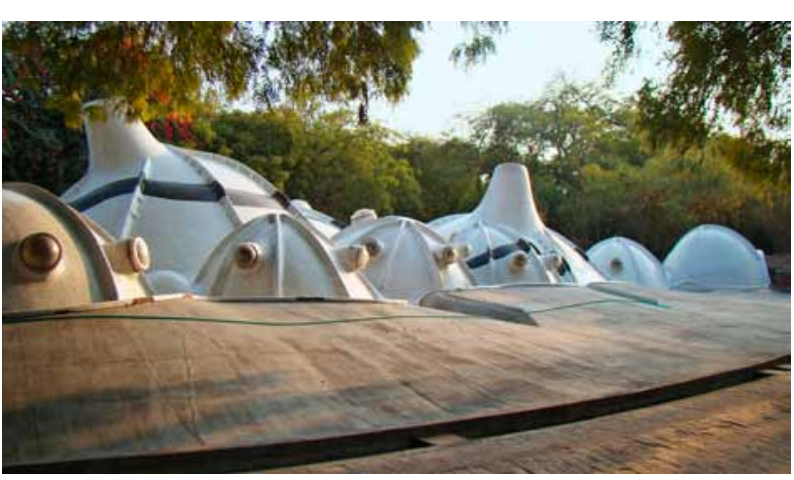

marked that the temples of Madurai were his learning grounds as were the studios of Le Corbusier (Alwin et al. 2008). In invoking Hindu mythologies as the cultural heritage of India, he pushed to the margins the very rich architectural practices of the Muslim and Christian populations of India. In crafting a new national identity with strong ties to the past, certain sections of Indians and their spatial practices were, therefore, lost.

\section{Conclusions}

When Chandigarh was built, architects from all over the world gathered to witness the inauguration of the new city. India's Prime Minister Nehru, standing before a vast crowd of officials, clerks, laborers, and children, took mortar from a silver bowl and set the cornerstone for a gigantic, tower-topped legislative hall. The building was the latest major edifice to get under way in the new capital of Punjab, replacing a site that only seven years ago was a cluster of mud hut villages on the grassy plain southwest of the Himalayas. Chandigarh was at the time one of the century's boldest schemes; a new city that marked an end to traditional building practices. A detailed study of the cosmic iconography, however, shows that Le Corbusier's plans did not eliminate tradition. The very foundation of his architectural modernism in India was based on traditions. His plans, however, redefined the meaning of tradition. These upheld Hindu traditions as normative. In a country like India that is home to a diverse population and a plethora of different languages, religions, and customs, defining tradition is nearly impossible. In his efforts to integrate architecture with nature/tradition, Le Corbusier fell back on Hindu cultural practices as Indian tradition. Indian architects like Doshi followed his footsteps and borrowed this idea of tradition. For that reason, the postcolonial discourse in architecture remained heavily inclined towards Hindu myths and religious traditions.

\section{References}

Alwin, J.; Lakshmanan, M.; Thomas, K. 2008. Transcript, DOSHI - a film by Premjit Ramachandran [online], [cited 02 November 2015]. Available from Internet: http://architexturez.net/doc/az-cf-166184

Constant, C. 1991. From Virgilian dream to Chandigarh: Le Corbusier and the modern landscape, in S. Wreke, W. H. Adams (Eds.). Denatured visions: landscape and culture in the twentieth century. New York: Museum of Modern Art.

Drew, J. B. 1961. Living: sector 22, Urban and Rural Planning Thought 2(4): 126-131.

Fig. 3. Hussain Doshi Gufa in Ahmedabad 
Doshi, B. V. 1986. Le Corbusier: acrobat of architecture B.V. Doshi interviewed by Carmen Kagal. Vistāra - The Architecture of India, Catalogue of the Exhibition, 204-221.

Doshi, B. V. 2009. Le Corbusier: a personal reading, in H. U. Khan, B. Julian (Eds.). Le Corbusier: Chandigarh and the modern city: insights into the iconic city sixty years later. Ahmedabad: Mapin Publisher.

Evenson, N. 1969. Le Corbusier: the machine and the grand design. London: Littlehampton Book Services.

Gandhi Bhawan. 2015 [online], [cited 27 November 2015]. Available from Internet: http://chandigarhtourism.gov.in/ photogallery5.htm

Joshi, K. 1999. Documenting Chandigarh: the Indian architecture of Pierre Jeanneret, Edwin Maxwell Fry, Jane Beverly Drew. Vol. 1. Ahmedabad: Map in association with Chandigarh College of Architecture.

Kalia, R. 1999. Chandigarh: the making of an Indian city. New Delhi: Oxford University Press.

Le Corbusier. 1961. The master plan, MARG 15(1): 5-19.

Le Corbusier. 1995. Oeuvre complète 1952-1957. 6th ed. Zurich Munchen London: Artemis.

Lightning at Chandigarh. 1959. The Sikh Times, 21 April.

Menin, S.; Samuel, F. 2002. Nature and space: Aalto and Le Corbusier. New York: Routledge.
Nehru, J. 1954. Speeches. Publication Division, Ministry of Information and Broadcasting, Government of India, Delhi.

Pandit, S. 1969. Chandigarh.

Prakash, V. 2002. Chandigarh's Le Corbusier: the struggle for modernity in postcolonial India. Seattle: University of Washington Press.

Randhawa, M. S. 1968. Chandigarh.

Scully, V. 1991. Architecture: the natural and the manmade. New York: St. Martin's Press.

The Establishment Statute of the Land. 1959. The Edict of Chandigarh plaque abbreviated from the document.

The Open Hand Monument [online]. 2015 [cited 21 November 2015]. Available from Internet: http://www.merachandigarh. com/tourist-attractions/open-hand-monument

\section{NABAPARNA GHOSH}

She is Dr, a lecturer of History at the University of Virginia. Before joining the University of Virginia, she graduated from Princeton University with a PhD in History. Research interests: urban history of South Asia with a focus on everyday life in the cities. 